\title{
Early Growth Response Protein 1
}

National Cancer Institute

\section{Source}

National Cancer Institute. Early Growth Response Protein 1. NCI Thesaurus. Code C99601.

Early growth response protein 1 ( $543 \mathrm{aa}, \sim 58 \mathrm{kDa}$ ) is encoded by the human EGR1 gene.

This protein is involved in the modulation of both mitogenesis and differentiation through the transcriptional regulation of specified genes. 